INTERNATIONAL JOURNAL OF RESEARCHES IN BIOSCIENCES, AGRICULTURE AND TECHNOLOGY

(C) VISHWASHANTI MULTIPURPOSE SOCIETY (Global Peace Multipurpose Society) R. No. MH-659/13(N) www.vmsindia.org

\title{
STUDY OF ANTIMICROBIAL FINISHES ON TEXTILES USING NATURAL HERBAL EXTRACTS
}

\author{
A. K. Mishra ${ }^{1}$, V. S. Wadhai ${ }^{2}$ and R. P. Sontakke ${ }^{3}$ \\ 1, Sardar Patel Mahavidyalaya, Chandrapur, (M.S), India \\ 2,S P College, Chandrapur, Janata Mahavidyalaya, Chandrapur \\ 3,Textiles Committee, Ministry of Textiles, Govt. of India, Mumbai (M.S), India
}

\begin{abstract}
:
An important and growing part of the textile industry is the medical and related healthcare and hygiene sector. The extent of the growth is due to constant improvements and innovations in both textile technology and medical procedures. In this study, coated textile dressing fabric was immersed with Turmeric, Honey and Henna, and its antibacterial properties were those treated with TiO2 nanoparticles. The aim of this research work is to highlight the specific application of textile in medical and surgical field and its biotechnological applications using nanotechnology for which textile materials are currently used.
\end{abstract}

Keywords : Technical textiles, Antimicrobial dressing, Meditech, Nanoparticles, Turmeric.

\section{Introduction:}

The Textile industry

in India traditionally, after agriculture, is the only industry that has generated huge employment for both skilled and unskilled labor in textiles. The textile industry continues to be the second largest employment generating sector in India. It offers direct employment to over 35 million in the country.[1] The share of textiles in total exports was $11.04 \%$ during April-July 2010, as per the Ministry of Textiles. During 2009-2010, Indian textiles industry was pegged at US\$55 billion, 64\% of which services domestic demand.[1] In 2010, there were 2,500 textile weaving factories and 4,135 textile finishing factories in all of India.

Textile sector is the oldest and largest manufacturing sector in India. During the past decade, Indian textile industry was plagued with many issues such as regulations regarding to licensing and policy distortions which had fragmented the industry. It was a roller coaster ride for the Indian textile sector. It was not able to capitalize more on the global trade regime. Indian textile sector saw countries like China Bangladesh, Sri Lanka, and Pakistan racing ahead of it even without any significant upstream textile industry strength. Despite all concerns, the industry saw a GDP of more than $6 \%$.

Technical textiles consumption under Meditech is estimated at Rs 1,514 crore. Surgical dressing alone accounts for over $50 \%$ of the total technical textile consumption across Meditech segment. Surgical sutures account for around $21 \%$ of the total Meditech consumption followed by contact lenses and artificial implants with shares of around $12 \%$ and $8 \%$ respectively in the total consumption. Meditech products will prevent hospital acquired infection, cross- infection, and provide savings in overall healthcare costs due to reduced crossinfections. Improved Meditech products will provide comfort and quicker healing.

Textiles have found numerous medical applications in life today, e.g., surgical hoses, hernia meshes, vascular substitutes and filters for blood dialysis. Dialyser membranes used to be made primarily of cellulose (derived from cotton linter). Many of the plants used for dye extraction are classified as medicinal, and some of these have recently been shown to possess remarkable antimicrobial activity [4]. Several sources of plant dyes rich in naphthoquinons such as lawsone from henna, juglone from walnut, and lapachol from alkanet are reported to exhibit antibacterial and antifungal activities $[5,10]$. Curcuma longa, also known as 'turmeric', is used as a coloring agent, and has medicinal properties. Various sesquiterpenes and curcuminoids have been isolated from the rhizome of C. longa, attributing to its biological characteristics such as antioxidant, antiinflammatory, wound healing, anticancer, antiproliferative, antifungal, and antibacterial properties [3,11]. In this study, coated textile dressing fabric was immersed with Turmeric, Honey and henna, and its antibacterial properties were those treated with $\mathrm{TiO} 2$ nanoparticles.

The aim of this research work is to highlight the specific application of textile in medical and surgical field and its biotechnological applications using nanotechnology for which textile materials are currently used.

Materials and Method:

Preparation of functionalized nanoparticles 
In this study, the textile dressing fabric, turmeric, Honey and henna powders were used throughout experiments. $\mathrm{TiO} 2$ nanoparticles were purchased from Merk Co., Ltd. $3 \mathrm{~g}$ of Turmeric, Honey and Henna powder were dissolved in respective $40 \mathrm{ml}$ of distilled water, and temperature was gradually raised to $90^{\circ} \mathrm{C}$ over $30 \mathrm{~min}$ and maintained at $90^{\circ} \mathrm{C}$ for $5 \mathrm{~min}$. Submerged respective sample in the obtained in Turmeric, Honey and Henna powder + nanofluid $0.33 \%(\mathrm{w} / \mathrm{v})$ under magnetic field, and extemporaneously dried (due to the convenient volatility of chloroform).

\section{Textile dressing coating}

In order to obtain the coated textile dressing, the textile material recommended for otomastoiditis, nasal-sinus, and cervical wound dressing (obtained from the local provider of Appllo hospital Ludhiana was aseptically cut in samples of $1 \mathrm{~cm} 2$, submerged in the obtained respective antimicrobial agents

\section{Microbial adherence to uncoated/coated textile dressing \\ AATCC Test Method 100-1999}

This test method provided a quantitative procedure for the evaluation of the degree of antibacterial activity. Assessment of antibacterial finishes on textile materials was determined by the degree of antibacterial activity intended in the use of such materials.

\section{Quantitative Test (Reference or Confirmatory Test)}

Size and shape of treated swatches: Circular swatches $4.8 \pm 0.1 \mathrm{~cm}(1.9 \pm 0.03$ in. $)$ in diameter, from the test fabric (preferably with a steel die) were cut. Swatches were stacked in a $250 \mathrm{~mL}$ wide-mouth glass jar with screw cap.

\section{Procedure:}

A shaken 24 h Staphylococcus aureus culture was let to stand for 15-20 min before preparing the inoculum. Swatches were aseptically transferred to the jar. Jar tops were screwed tightly to prevent evaporation. The neutralizing solution was included with ingredients to neutralize the specific antibacterial fabric treatment and to take care of any $\mathrm{pH}$ requirements of the fabrics (from finishes, antibacterial agents, etc.). The neutralizing solution employed was reported. Additional jars containing inoculated untreated control swatches and jars containing inoculated treated test swatches were incubated at $37 \pm$ $2{ }^{\circ} \mathrm{C}\left(99 \pm 3^{\circ} \mathrm{F}\right)$ for $18-24 \mathrm{~h}$. Similar jars were also incubated over other periods (e.g., 1 or $6 \mathrm{~h}$ ) to provide information about the bactericidal activity of the treatment over such periods.

After incubation, $100 \pm 1 \mathrm{~mL}$ of neutralizing solution to jars containing untreated control swatches and to jars containing treated test swatches was added. Jars were shaken vigorously for one minute.Serial dilutions were made and plated (in duplicate) on nutrient agar. Dilutions of $10^{\circ}$, $10^{1}, 10^{2}$ were usually suitable for treated test fabrics. Several different dilutions were required for untreated control fabrics depending on the incubation period.

\section{AATCC Method 147}

\section{Procedure}

Sterilized nutrient agar [cooled to $47 \pm 2^{\circ} \mathrm{C}(117$ $\pm 4^{\circ} \mathrm{F}$ )]was dispenced by pouring $15 \pm 2 \mathrm{ml}$ into each standard (15x $100 \mathrm{~mm})$ flat bottomed petri dish. Agar was allowed to get firm before inoculating. Inoculum was prepared by transferring $1.0 \pm 0.1 \mathrm{~mL}$ of a $24 \mathrm{~h}$ broth culture into $9.0 \pm 0.1 \mathrm{~mL}$ of sterile distilled water contained in a small flask. It was mixed well using appropriate agitation.Using a $4 \mathrm{~mm}$ inoculating loop, one loopful of the diluted inoculum was loaded and transfered to the surface of the sterile agar plate by making five streaks approximately $60 \mathrm{~mm}$ in length, spaced $10 \mathrm{~mm}$ apart covering the central area of a standard petri dish without refilling the loop. It was taken care that no surface breakage should take place while making the streaks.

Fastness properties to washing, rubbing and perspiration were measured according to a standard method DIN EN ISO 105-CO6 (May 1997); AATCC Test Method 8 (2005); and DIN EN ISO 105-EO4 (June 1986).

\section{Results and discussion:}

Antimicrobial Property

Table 1 Antibacterial activity of Natural agent against Gram+/- Bacteria

\begin{tabular}{|c|c|c|c|c|c|c|c|}
\hline & & \multicolumn{6}{|l|}{ Inhibition Zone in diameter in mm/1 cm Sample } \\
\hline Sr.No & Conc. of nano particles in ppm & Turmeric & \multicolumn{2}{l|}{ Honey } & \multicolumn{2}{l|}{ Henna } \\
\hline & & $\begin{array}{l}\text { E.coli } \\
(G-v e)\end{array}$ & $\begin{array}{l}\text { S.aureus } \\
(G+v e)\end{array}$ & $\begin{array}{l}\text { E.coli } \\
(G-v e)\end{array}$ & $\begin{array}{l}\text { S.aureus } \\
(G+v e)\end{array}$ & $\begin{array}{l}\text { E.coli } \\
(G-v e)\end{array}$ & $\begin{array}{l}\text { S.aureus } \\
(G+v e)\end{array}$ \\
\hline 1 & & 0 & 0 & 0 & 0 & 0 & 0 \\
\hline 2 & 0 & 15 & 14 & 11 & 10 & 10 & 09 \\
\hline 3 & 25 & 18 & 16 & 14 & 12 & 14 & 14 \\
\hline 4 & 50 & 17 & 20 & 15 & 15 & 16 & 14 \\
\hline
\end{tabular}


Table 2 Antibacterial activity of Natural agent + TiO2 nanoparticles against Gram+/- Bacteria

\begin{tabular}{|c|c|c|c|c|c|c|c|}
\hline & & \multicolumn{5}{|c|}{$\begin{array}{l}\text { Inhibition Zone in diameter } \\
\text { in mm / cm Sample }\end{array}$} \\
\hline Sr. No & $\begin{array}{l}\text { Conc. of nano } \\
\text { particles in } \\
\text { ppm }\end{array}$ & $\begin{array}{l}\text { Turmeric }+ \\
\text { TiO2 } \\
\text { nanoparticles }\end{array}$ & \multicolumn{2}{l|}{$\begin{array}{l}\text { Honey + TiO2 } \\
\text { nanoparticles }\end{array}$} & $\begin{array}{l}\text { Henna + TiO2 } \\
\text { nanoparticles }\end{array}$ \\
\hline & & $\begin{array}{l}\text { E.coli } \\
(G-v e)\end{array}$ & $\begin{array}{l}\text { S.aureus } \\
(G+\text { ve })\end{array}$ & $\begin{array}{l}\text { E.coli } \\
(G-v e)\end{array}$ & $\begin{array}{l}\text { S.aureus } \\
(G+v e)\end{array}$ & $\begin{array}{l}\text { E.coli } \\
(G-v e)\end{array}$ & $\begin{array}{l}\text { S.aureus } \\
(G+v e)\end{array}$ \\
\hline 1 & 0 & 0 & 0 & 0 & 0 & 0 & 0 \\
\hline 2 & 25 & 19 & 20 & 15 & 16 & 18 & 17 \\
\hline 3 & 50 & 23 & 25 & 17 & 19 & 20 & 21 \\
\hline 4 & 100 & 25 & 28 & 20 & 22 & 22 & 23 \\
\hline
\end{tabular}

Table-3 summary of the antibacterial activities

\begin{tabular}{|l|l|c|c|}
\hline $\begin{array}{l}\text { Sr. } \\
\text { No }\end{array}$ & \multicolumn{3}{|l|}{$\begin{array}{l}\text { Inhibition Zone in diameter } \\
\text { in mm/1 cm Sample }\end{array}$} \\
\hline & $\begin{array}{l}\text { Antimicrobial } \\
\text { Agent (50 ppm) }\end{array}$ & $\begin{array}{l}\text { E.coli } \\
(G-v e)\end{array}$ & $\begin{array}{l}\text { S.aureus } \\
(G+v e)\end{array}$ \\
\hline 1 & Turmeric & 5 & 5 \\
\hline 2 & Honey & 3 & 3 \\
\hline 3 & Henna & 2 & 3 \\
\hline 4 & $\begin{array}{l}\text { Turmeric + } \\
\text { TiO2 nanoparticles }\end{array}$ & 8 & 9 \\
\hline 5 & $\begin{array}{l}\text { Honey + } \\
\text { TiO2 nanoparticles }\end{array}$ & 4 & 5 \\
\hline 6 & $\begin{array}{l}\text { Henna + } \\
\text { TiO2 nanoparticles }\end{array}$ & 5 & 4 \\
\hline
\end{tabular}

For imparting antibacterial properties, Turmeric, Honey and Henna powder are used. The effect of Turmeric concentration on antimicrobial properties is optimum. It is found that the use Turmeric is good results are observed for E. coli (G- ) and Staphylococcus aureus $(\mathrm{G}+)$ Table-1. Table-2 shows a summary of the antibacterial activities of the samples treated with Turmeric, Honey and Henna in combination with $\mathrm{TiO} 2$ nanoparticles. Table-3 shows a summary of the antibacterial activities of the samples treated with Turmeric, Honey and Henna in combination with $\mathrm{TiO} 2$ nanoparticles after 10 washings, respectively

\section{Fastness Properties}

The overall fastness properties improve by using $\mathrm{TiO} 2$ nanoparticles. This may be due to the fact that $\mathrm{TiO} 2$ enhances the unsaturation site of the vinyl group which is responsible for the fixation of dispersed pigment during thermofixatioin through the polymerization process. The fastness properties in case of using $\mathrm{TiO} 2$ nanoparticles, the colour fastness to washing, rubbing and perspiration ranges from good to very good.

\section{Conclusion:}

The application of textile in high performance and specialised fields are increasing day by day including medical field. As the medical textiles are directly linked to human beings, its importance cannot be neglected. Medical textiles are already used in various fields such as implanted materials, healthcare and hygienic products. There is a wide scope of applications of textile materials in the medical fields, which requires lot of research activities. Indian textile industries with medical field experts have an important role to play in this niche market as medical textiles not only have great demand in the domestic market but also have export potential.

As the concentration of Turmeric increases with antibacterial properties of fabrics also increase. Using $\mathrm{TiO} 2$ the antimicrobial property was optimized against Escherichia coli (G- ) and Staphylococcus aureus $\left(G^{+}\right)$.

Durability of antibacterial activity to laundering was also investigated. The results indicated that treated fabrics with these natural dyes had excellent antibacterial activity as well as $\mathrm{TiO} 2$ nanoparticles before and after wash. For overall fastness properties based on tilldate work it is assumed that it improves by using TiO2 nanoparticles. Biomaterials for the last few decades have been found to generate considerable interest in the biomedical fields covering the area of wound dressings, sutures and tissue engineering.

\section{References:}

1. "A BRIEF REPORT TEXTILE INDUSTRY IN INDIA January, 2010".

\section{American Association of Textile Chemists and Colorists (AATCC TECHNICAL MANUAL), Volume 85, 2010, $142 \& 251$}

3. Barik, A., Mishra, B., Kunwar, A., Kadam, R.M., Shen, L., Dutta, S., Padhye, S., Satpati, A.K., Zhang, H.Y., Priyadarsini, K.I.,(2007) : Comparative study of copper(II) ecurcumin complexes as superoxide dismutase mimics and free radical scavengers. Eur. J. Med. Chem.42:Pp 431-439.

4. Gerson, H. (1975): Fungi toxicity of 1,4-napthoquinones to Candida albicans and Trichophyton 
mentagrophytes. Can. J. Microbiol. 21:Pp 197-205.

5. Gulrajani, M.L., Gupta, D., (2001) : Wash fastness tests to test durability. In: NCUTE Workshop on Dyeing and Printing with Natural Dyes, Pp. 3-5.

6. Hussein, S.A.M., Barakat, H.H., Merfort, I., Nawwar (1997), MAM: Tannins from the leaves of Punica granatum. Photochemistry 45, Pp 819823.

7. Machado, T.B., Pinto, A.V., Pinto, M., Leal, I.C., Silva, M.G., Amaral, A.C., Kuster, R.M., Netto- dosSantos, K.R.,(2003) : In vitro activity of Brazilian medicinal plants, naturally occurring naphthoquinones and their analogues, against methicillinresistant Staphylococcus aureus. Int. Antimicrob. Agents 21,:Pp 84-279.

8. Mirjalili and Abbasipour: Journal of Nanostructure in Chemistry (2013),3:37
9. http://www.jnanochem.com/content/3 $/ 1 / 37$

10. Othmers, K.,: Encyclopedia of chemical technology(1967). Interscience 7, Pp 7-81.

11. Schuerch, A.R.,: Wehrli, W.,(1978): beta-Lapachone, an inhibitor of oncornavirus reverse transcriptase and eukaryotic DNA polymerase-alpha inhibitory effect, thiol dependence and specificity. Eur. J. Biochem. 84, Pp197205.

12. Singh, R., Jain, A., Panwar, S., Gupta, D., Khare, S.K.,(2005): Antimicrobial activity of some natural dyes.Dyes and Pigment 66, Pp 99-102.

13. Wagner, H., Kreher, B., Lotter, H., Hamburger, M.O., Cordell, GA(1978): Structure determination of new isomeric naphthol $[2,3,-$ b] furan- 4,9-diones from Tabebuia avellanedae by the selective INEPT technique. Helv. Chim. Acta 72:Pp 67-659 